\title{
Companhia Estrada de Ferro D. Pedro II: a grande escola prática da nascente Engenharia Civil no Brasil oitocentista
}

\author{
Pedro Eduardo Mesquita de Monteiro Marinho*
}

\section{RESUMO}

$\mathrm{Na}$ formação social brasileira, ao final do século XIX, a conflituosa correlação de forças que sustentava o bloco no poder passou a demonstrar a perda da capacidade de formulaçôes intelectuais capazes de articular reformas compatíveis com o momento histórico. Em linhas gerais, engenheiros passaram a atuar como técnicos e como dirigentes nas Companhias de Estradas de Ferro, cuja função particular articulava-se, naquele momento, aos interesses das fraçóes do complexo agroexportador de determinadas regióes do país. Dessa forma, acreditamos ser possível explicar como os projetos ligados às ferrovias desdobravam-se de forma a extrapolar a sociedade civil em direção à sociedade política, revelando, assim, o processo de ampliação do Estado brasileiro.

Palavras-chave: estradas de ferro; história da engenharia; Brasil do século XIX; Segundo Reinado; história da técnica e tecnologia.

\section{ABSTRACT}

In Brazilian society, in the late nineteenth century, the conflicting correlation of forces that supported the power bloc went on to demonstrate the loss of ability to intellectual formulations capable of articulating reforms compatible with the historic moment. In general, engineers started to work as technicians and as leaders in railway companies, whose particular function articulated the interests of the agro-export complex fractions of certain regions of the country. Thus, we believe we can explain how the projects related to railways unfolded in order to extrapolate the civil society towards the political society, revealing thus the process of expansion of the Brazilian state.

Keywords: railroads; history of engineering; nineteenth-century Brazil; Second Empire; history of technology.

Artigo recebido em 26 de dezembro de 2014 e aprovado para publicação em 30 de abril de 2015.

DOI - http://dx.doi.org/10.1590/2237-101X016030008

* Doutor em História pela Universidade Federal Fluminense (UFF) e pesquisador do Museu de Astronomia e Ciências Afins (MAST). Rio de Janeiro, RJ, Brasil. E-mail: pedromarinho@yahoo.com.br. 


\section{Introdução}

O período privilegiado por este artigo — as três últimas décadas do século XIX tem sido objeto de vasta literatura historiográfica, sobretudo devido aos primeiros sinais do processo de industrialização que se implantava no país e aos marcos formais referentes à abolição do trabalho escravo (e à transição para o trabalho livre), bem como ao golpe republicano. Malgrado as particularidades regionais, podemos afirmar que esses e outros aspectos específicos do período assinalam um processo corrente de acumulaçáo capitalista, com mudanças profundas nas relações de trabalho e nas formas de produção no campo e nas cidades em quase todo o país. Nesse contexto, destacou-se uma fração agrária ligada à produção e à exportação de café, cujas lavouras se concentravam no eixo centro-sul. Esse grupo atingirá a hegemonia dentro dos complexos agroexportadores da época, ainda que estivesse sub-representado no bloco no poder imperial. ${ }^{1}$

A cultura do café percorreu grande parte da história do império, adiantando-se nos anos 30 do século XIX pelo Vale do Paraíba, contando com novas frentes de expansão ao longo das décadas posteriores. Grande parte da historiografia especializada ressalta que tanto o café quanto as ferrovias, que vieram a reboque, foram responsáveis pela implantaçáo da indústria no Brasil. Dessa forma, considerou-se importante observar como o capital cafeeiro, predominante até a década de 1920 do último século, se apresentou sob as mais diferentes formas, quais sejam as de capital agrário, industrial, bancário e comercial, sendo o próprio capital cafeeiro um investimento industrial, inclusive com a intensificação progressiva da mecanização.

Aliás, tal aspecto industrial da produção cafeeira não passara despercebido aos olhos dos observadores da época, como, por exemplo, Delgado de Carvalho, para quem a aparelhagem da usina de café atingiu um grau de perfeição muito notável em São Paulo. É hoje a indústria melhor organizada do Brasil. As grandes fazendas de São Paulo são instalaçóes modelo, que surpreendem o viajante estrangeiro e sáo dignas de figurar ao lado das indústrias mais bem aparelhadas da Europa. ${ }^{2}$

Além disso, o desenvolvimento crescente da cultura do café demandou todo um aparato de infraestrutura, que passava por empresas de serviços, casas bancárias, comerciais e empresas voltadas para implementação de transportes urbano e ferroviário. Da mesma forma, à ampliação da produção de café para exportação seguiu-se a instalaçâo de estabelecimentos de importação e exportação responsáveis por todo o tipo de comércio realizado dentro e fora das fronteiras do país. Ou seja, a atividade cafeeira deu origem a um significativo "com-

\footnotetext{
${ }^{1}$ MENDONÇA, Sonia Regina de. Ruralismo: agricultura, poder e Estado na Primeira República. v. 1. Tese (doutorado em História) — Universidade de São Paulo, São Paulo, 1990. p. 46.

${ }^{2}$ CARVALHO, Delgado apud SILVA, Sergio. Expansão cafeeira e origens da indústria no Brasil. 5. ed. São Paulo: Alfa-Ômega, 1981. p. 56.
} 
plexo econômico", segundo parte da historiografia especializada. Tais aspectos reforçam o momento de industrialização - estreitamente dependente do capital estrangeiro - e a inserção do país no contexto do capitalismo internacional.

\section{Do café às ferrovias: relaçóes com a nascente engenharia civil no Brasil oitocentista}

John Wirth afirma que, até 1900, Minas manteve-se como segundo produtor brasileiro de café, logo atrás de São Paulo. Contudo, ainda que o território fosse bem servido de estradas de ferro, o estado apresentava algumas desvantagens em relação a São Paulo, como terras menos produtivas e salários menores pagos pelos produtores em relação aos dos paulistas. O declínio dos preços do café na década de 1890 teria resultado, também, num empecilho para a importaçáo de produtos básicos que os produtores mineiros haviam deixado de produzir para dedicarem-se à monocultura. ${ }^{3}$ Mendonça, por sua vez, apresenta um a um os fatores que levaram à decadência da cafeicultura no território fluminense, ocorrida a partir do último quartel do século XIX. Dentre eles, destaca-se a diminuiçáo das margens de lucro da empresa cafeeira de exportação devido à dificuldade de adaptação da produção às novas condiçôes do período, especialmente aquelas relacionadas com o encarecimento de mão de obra escrava. ${ }^{4}$ Uma das tentativas de reajuste da cafeicultura fluminense, nas décadas de 1860 e 1870, com vista a racionalizar o estoque de mão de obra existente, foi a construção de estradas de ferro, que permitiria a liberação do braço escravo — desviado para a condução de mulas - a fim de ser aproveitado nas lavouras de café.

Decerto, é importante ressaltar que os empreendimentos ferroviários, de uma maneira geral, foram desenvolvidos visando a contemplar interesses e necessidades das fraçôes agroexportadoras no transporte do produto aos principais portos brasileiros. ${ }^{5}$ Conforme afirma Eduardo Gonçalves David, “... [o]s baróes do café exigiam meio de transporte mais eficiente que as tropas de mulas que serpenteavam pelas encostas íngremes da Serra do Mar em direção aos portos do rio Iguaçu, onde era o café embarcado em chatas, até a baía de Guanabara”. ${ }^{6}$

\footnotetext{
${ }^{3}$ WIRTH, John D. O fiel da balança: Minas Gerais na Federação Brasileira, 1889-1937. Rio de Janeiro: Paz e Terra, 1982.

${ }^{4}$ MENDONÇA, Sonia Regina de Mendonça. A primeira politica de valorização do café e sua vinculação com a economia agrícola do Estado do Rio de Janeiro. Dissertação (mestrado em História) — Universidade Federal Fluminense, Niterói, 1977.

${ }^{5}$ Cf. MARINHO, Pedro Eduardo Mesquita de Monteiro. Engenharia imperial: o Instituto Politécnico Brasileiro — (1862-1880). Dissertação (mestrado em História) — PPGH da Universidade Federal Fluminense. Niterói: UFF, 2002.

${ }^{6}$ DAVID, Eduardo Gonçalves. A ferrovia e sua história. Estrada de Ferro Central do Brasil. Rio de Janeiro: AENFER, 1998, p. 5. Geraldo Beauclair assinala que "o alento que a expansão cafeeira ganharia com as Estradas de Ferro (Pedro II, Cantagalo, Mauá-Serra da Estrela) ensejava, como contrapartida, o declínio dos pequenos portos disseminados junto às águas reduzindo o sistema regional de navegação. OLIVEIRA,
} 
Desse modo, as construçóes em benefício do complexo produtivo do café se realizaram a partir de múltiplos interesses de agentes que, inclusive, se confrontavam dentro do mesmo campo agroexportador. As pressóes feitas por cafeicultores de distintas regióes do país acabavam resultando no incremento de empreendimentos ferroviários cujo fim último seria diminuir o custo do transporte da produção para a exportação de uma determinada região e, muitas vezes, de um fazendeiro em particular. ${ }^{7}$

Uma vez que as lavouras do café, já no final do século em questão, tenderam à relativa decadência em algumas províncias e a um fortalecimento em outras, é possível concluir que as ferrovias, que funcionavam, de maneira geral, segundo as necessidades da economia cafeeira - e, portanto, dos agentes vinculados ao complexo agroexportador — sofressem abalos ou ganhassem fôlego em regióes distintas. Andrea Fernandes Rabello, contudo, afirma que os fazendeiros da província fluminense viam nas estradas de ferro um investimento mais seguro, pois respondiam apenas pelo capital investido, cujo retorno, assegurado pela garantia de juros, era certo. ${ }^{8}$

Porém, é importante ressaltar que a maioria das formulaçôes da historiografia brasileira sobre as ferrovias, em sua maioria, repousa na noção de que modernidade e escravidáo não faziam parte do mesmo processo histórico, ou, dito de outro modo, que existia uma contradição entre desenvolvimento técnico a e escravidão. Ao apresentar a abolição como a consequência de um processo de longa duração que envolveu mudanças estruturais, situaçóes conjunturais e uma sucessão de episódios que culminaram na Lei Áurea, Emília Viotti da Costa, ${ }^{9}$ por exemplo, colocou em lados opostos os senhores escravistas do vale fluminense e do oeste paulista, onde os primeiros, mais que os segundos eram comprometidos com a escravidão. Assim, entre outros elementos apresentados pela eminente historiadora, as estradas de ferro fariam parte do processo do desenvolvimento capitalista do Brasil e estariam em contradição com a escravidão. Neste processo as ferrovias propiciaram a racionalização dos meios de transporte, o estímulo às novas atividades econômicas e à urbanizaçáo, e tudo isso teria garantido a possibilidade para o emprego do trabalho livre.

O resultado inevitável desta equação de longo tempo teria sido o seguinte: senhores do oeste paulista, mais afeitos à modernidade e menos apegados à escravidão, prosperaram. No revés desta moeda, os senhores escravistas fluminenses, por seu comprometimento com a escravidão, por sua não adesão aos novos tempos, fracassaram. Teriam deixado como legado,

Geraldo de Beauclair Mendes de. A construção inacabada: a economia brasileira, 1822-1860. Rio de Janeiro: Vício de Leitura, 2001, p. 210.

${ }^{7}$ MARINHO, Pedro Eduardo Mesquita de Monteiro. Engenharia imperial: o Instituto Politécnico Brasileiro - 1862-1880, op. cit.

${ }^{8}$ RABELLO, Andrea Fernandes Considera Campagnac. Os caminhos de ferro da Província do Rio de Janeiro. Ferrovias e café na $2^{\underline{a}}$ metade do século XIX. Niterói, 1996. Dissertação (mestrado em História) — Instituto de Ciências Humanas e Filosofia, Universidade Federal Fluminense, Niterói, 1996.

${ }^{9}$ COSTA, Emilia Viotti da. Da senzala à colônia. Sáo Paulo: Unesp, 1998. p. 20-30. 
assim como constatou Raimundo Faoro ${ }^{10}$ e antes dele Monteiro Lobato, ${ }^{11}$ ainda no início do século XX, as “cidades mortas”. Nesta oposição, as ferrovias fluminenses, e em particular a Estrada de Ferro Pedro II, não se destacaram como objeto de pesquisas, frente ao "caminho da modernidade" trilhado pelas estradas paulistas e mesmo de outras províncias, que atraíram a grande maioria dos estudos contemporâneos.

Não se pretende, aqui, entrar detalhadamente nas controvérsias da historiografia especializada sobre o tema, mas cabe ressaltar que, a partir das nossas pesquisas, ${ }^{12}$ temos percebido que as formaçóes das estradas de ferro do Brasil imperial inseriam-se em um movimento duplo e complexo, onde o moderno se nutriu do atraso e o complementou, acelerando a abolição em alguns contextos e "vivificando" a escravidão em outros. Ou, como em 1883 afirmava Joaquim Nabuco, "a escravidão havia sido 'vivificada' e alentada pelo vapor e pela locomotiva". ${ }^{13}$

Com a montagem do chamado complexo cafeeiro, na segunda metade do século XIX, a construção civil, sem dúvida uma das mais antigas atividades profissionais desenvolvidas no Brasil, ampliou imensamente suas perspectivas de atuação e, ao mesmo tempo, enfrentou desafios, tanto de ordem econômica quanto técnica. As grandes obras necessárias à criação da infraestrutura urbana, energética e de transportes construída nessa época ofereceram alguns desses desafios, que se confundem com as origens da engenharia como campo profissional e, ao mesmo tempo, com a formação de seus agentes, enquanto grupo social, a partir da autoridade intelectual acumulada.

Na década final do império brasileiro, com efeito, a engenharia civil encontrava-se, num primeiro momento, estreitamente vinculada à expansão e diversificação das condições de produção agrário-exportadora, portanto, vinculada igualmente aos agentes nela implicados. Tal processo dava-se concomitantemente no âmbito urbano - com os serviços de locomoção, calçamento, saneamento, gás, abastecimento de água — e, no âmbito rural, com a construção das estradas de ferro e das linhas telegráficas que as acompanhavam. Esta conjuntura guardava relação direta com a expansão capitalista e as concepçóes ideológicas burguesas de progresso, técnica e competência, que demandavam a formação de agentes técnico-científicos condicionados às funçóes mais complexas e, dessa maneira, dotados de capacidade para a execução e direção de atividades vinculadas ao desenvolvimento econômico. ${ }^{14}$

A atividade profissional dos engenheiros civis, que se complexificava com o processo de afirmação e institucionalização do campo, desprendia-se de aspectos estritamente técnicos para formular, dirigir e executar diversas etapas de uma unidade de produção, onde ca-

${ }^{10}$ FAORO, Raymundo. A questão nacional: a modernização. Estudos Avançados, v. 6, n. 1, p. 7-22, 1992.

${ }^{11}$ LOBATO, José Bento Monteiro. Cidades mortas. São Paulo: Globo Livros, 2007 [1919].

${ }^{12}$ MARINHO, Pedro Eduardo Mesquita de Monteiro. Ampliando o estado imperial: os engenheiros e a organização da cultura no Brasil oitocentista, 1874-1888. Tese (doutorado) — Universidade Federal Fluminense, Instituto de Ciências Humanas e Filosofia, Departamento de História, 2008.

${ }^{13}$ NABUCO, Joaquim. O abolicionismo. Petrópolis: Vozes, 1988 [1883]. p. 122.

${ }^{14}$ MARINHO, Pedro Eduardo Mesquita de Monteiro. Engenharia imperial: o Instituto Politécnico Brasileiro - 1862-1880, op. cit., a partir da p. 120. 
biam funçôes também financeiras e comerciais, tornando essas tarefas de competência dos engenheiros. Aliás, são os principais profissionais a dominar a matemática aplicada. Desta maneira, os aspectos financeiros relacionados com os de execução técnica permitirão aos engenheiros, cada vez mais, a capacidade de racionalização da produção, o que os coloca em posiçôes de autoridade perante outros agentes contemporâneos. Assim, cada vez mais engenheiros-empresários começam a ser gestados em um processo de expressivo aumento da demanda das fraçôes hegemônicas pelo trabalho destes profissionais. ${ }^{15}$ As frentes de trabalho se multiplicavam, mas o que aparecia em destaque era a demanda relativa a toda a sorte de obras públicas nas cidades e de atividades diretamente ligadas à construção e administração de estradas de ferro - ainda que, inicialmente, a participaçáo do engenheiro brasileiro tenha ocorrido na qualidade de auxiliar dos engenheiros ingleses. Ao longo desse processo, os profissionais ligados à engenharia brasileira conseguiram galgar gradativamente postos de direção. Trajetória que pode ser observada principalmente em relação às ferrovias nacionais. Na Estrada de Ferro D. Pedro II (EFDPII), por exemplo, principal ferrovia do país, todos os importantes postos de direção já eram ocupados por engenheiros brasileiros no início da década de 1870.

Em meio ao apogeu da cultura cafeeira no Vale do Paraíba, para cumprir o papel de levar os trilhos até as margens do rio Paraíba do Sul e de lá desdobrar-se em direçôes opostas, com vistas a alcançar as províncias de São Paulo e Minas, nasceu, não sem conflitos, a CEFDPII; Companhia Estrada de Ferro D. Pedro II. Em nossa análise, ${ }^{16}$ entendemos que embora a Estrada de Ferro D. Pedro II, construída e administrada pela Companhia de mesmo nome, não tenha sido a primeira ferrovia do Brasil, foi o resultado possível do processo de embates entre a sociedade e o governo, iniciado em 1835. Das tensões em torno do caminho de ferro que iria transpor a Serra do Mar se formaram as bases para a implantação de ferrovias no Brasil. As estradas de ferro compunham parte da agenda das políticas públicas que envolvia as obras de infraestrutura, ou, como no linguajar de época, ${ }^{17}$ os "melhoramentos materiais". ${ }^{18}$ Ferrovias e outros melhoramentos de infraestrutura que já vinham sendo pensados antes começavam a sair do papel, ou melhor, foram retomadas a partir de 1848,

\footnotetext{
${ }^{15}$ Ibidem.

${ }^{16}$ MARINHO, Pedro Eduardo Mesquita de Monteiro. Ampliando o estado imperial: os engenheiros e a organização da cultura no Brasil oitocentista, 1874-1888, op. cit.

${ }^{17}$ MARINHO, Pedro Eduardo Mesquita de Monteiro. Ampliando o estado imperial: os engenheiros e a organização da cultura no Brasil oitocentista, 1874-1888, op. cit.

${ }^{18}$ De acordo com o Diccionario da Lingua Portugueza, datado de 1889, da autoria de Antonio Morais Silva, a definição para "melhoramentos públicos" referia-se às "obras de utilidade ou embelezamento feitas pelo Estado, pelo município, etc. para uso e gozo da população: v.g. abertura de ruas, praças, abastecimento de águas, esgotos, iluminação, viação acelerada, edificaçóes, jardins, etc." Cf. SILVA, Antonio Morais. Diccionario da lingua portugueza. Rio de Janeiro: Editora Empreza Litteraria Fluminense de A. A. da Silva Lobo, 1889. Os referidos melhoramentos possuíam uma relação direta com o trabalho dos engenheiros e, por sua vez, com as obras públicas no século XIX. Além disso, estes melhoramentos poderiam ser tanto "materiais", "morais" ou "públicos", como também "urbanos".
} 
em grande medida, a partir de uma linha política conservadora e modernizante, impressa pela trindade saquarema, ${ }^{19}$ a exemplo do Decreto no 641, de 26 de julho de 1852, que reorganizou a concessão de linhas férreas para integrar a corte, a região do Vale do Paraíba e as províncias de São Paulo e Minas Gerais através da Serra do Mar. ${ }^{20}$

Ao mesmo tempo que se demandava o trabalho dos engenheiros civis para as obras de infraestrutura, o crescimento das cidades ampliava ainda mais sua atuação em diferentes campos e, consequentemente, aumentava a necessidade de novos e maiores espaços para as suas discussóes profissionais. Poder-se-iam encontrar, de maneira frequente, naquele período, publicaçôes de artigos e realização de debates dos engenheiros cujas temáticas estavam relacionadas com os chamados "melhoramentos" urbanos. Nas revistas científicas em especial, os agentes costumavam registrar a questão das obras públicas, particularmente estradas de ferro, como um dos assuntos mais recorrentes, demonstrando o envolvimento intenso de sua prática profissional ao processo de crescimento e transformação do espaço urbano na virada do século e, consequentemente, os estreitos vínculos com as frações agrárias hegemônicas, conforme já apontamos.

É possível perceber, por exemplo, que nas sessôes do Instituto Politécnico Brasileiro (IPB), de 1862 a 1880, assim como nas memórias publicadas na Revista do Instituto, preponderaram temas relativos ao planejamento, construção e administração geral de ferrovias. Dos estudos premiados com a medalha Hawkshaw, ${ }^{21} 35,7 \%$ diziam respeito a estradas de ferro. ${ }^{22}$

Da mesma forma, como podemos verificar na tabela 1 , o tema de maior destaque na Revista do Clube de Engenharia, cuja primeira publicação data de 1887, prossegue referente às estradas de ferro, seguido de obras públicas:

\footnotetext{
${ }^{19}$ MARINHO, Pedro Eduardo Mesquita de Monteiro. Engenharia imperial: o Instituto Politécnico Brasileiro (1862-1880), op. cit.

${ }^{20}$ MATTOS, Ilmar Rohloff de. O tempo saquarema: a formação do estado imperial. São Paulo: Hucitec, 2004. p. 182-189.

${ }^{21}$ Prêmio anual oferecido pelo IPB ao melhor trabalho de engenharia. As ferrovias empregaram um número alto de engenheiros brasileiros: $75 \%$ de todos eles por volta de 1880, nem todos no serviço público, porque diversas estradas de ferro eram exploradas por companhias estrangeiras (São Paulo Railway, Brazil Railway Co., Cie. Générale de Chemins de Fer du Brésil, entre outras) por concessão do Estado.

${ }^{22}$ RIPB, Tomo XII, 1878, 2ª parte, p. 3; Apud MARINHO, Pedro Eduardo Mesquita de Monteiro. Engenharia imperial: o Instituto Politécnico Brasileiro (1862-1880), op. cit.
} 
Tabela 1

Temáticas da Revista do Clube de Engenharia (1887-1910)

\begin{tabular}{|c|c|}
\hline Temas & Total \\
\hline Estradas de Ferro & 95 \\
\hline Abastecimento de água & 23 \\
\hline Saneamento & 18 \\
\hline Portos & 12 \\
\hline Máquinas a vapor & 7 \\
\hline Navegação & 6 \\
\hline Eletricidade & 4 \\
\hline Telegrafia & 4 \\
\hline Telefonia & 2 \\
\hline Aço & 2 \\
\hline Cimento Portland & 1 \\
\hline Vários & 22 \\
\hline
\end{tabular}

Fonte: Revista do Clube de Engenharia. Rio de Janeiro: Imprensa a Vapor Lombaerts \& C. / Tip. Leuzienger $\&$ Filhos (1887-1910). ${ }^{23}$

Além da publicação de temáticas ligadas às obras públicas em revistas das próprias agremiaçôes, a organização de congressos conseguia reunir um número expressivo de agentes com o propósito de discutir diretrizes para a política de incremento da infraestrutura das ferrovias no país. Nesse sentido, as problemáticas formuladas e debatidas por aqueles intelectuais em suas reunióes cotidianas tornavam-se temas de seus congressos, aptos a promover as mais diversas campanhas, resultando na consolidação daqueles agentes como intelectuais organizadores da cultura. Algumas resoluçóes formuladas nesses eventos foram registradas em relatórios e pareceres, cujo conteúdo é passível de revelar não apenas a preeminência de um grupo particular, mas também certas contendas estabelecidas entre os agentes sobre os assuntos em questáo. Na década de 1880, dois encontros ganharam destaque: o 1 Congresso das Estradas de Ferro do Brasil, em 1882, e a 1ㄹ Exposição das Estradas de Ferro do Brasil, realizada em 1887, nos quais se reuniram diversos dirigentes do Clube de Engenharia. ${ }^{24}$

\footnotetext{
${ }^{23}$ Apud MARINHO, Pedro Eduardo Mesquita de Monteiro. Ampliando o estado imperial: os engenheiros e a organização da cultura no Brasil oitocentista, 1874-1888, op. cit.

${ }^{24}$ MARINHO, Pedro Eduardo Mesquita de Monteiro. Porta-vozes em uma era de incertezas: o Clube de Engenharia e a concepção de uma Inspetoria Geral das Estradas de Ferro. Revista Brasileira de História da Ciência, v. 3, p. 170-183, 2010.
} 
Tabela 2

Temários discutidos no 1ำ CEFB

\begin{tabular}{|c|c|c|}
\hline Dia da Sessão & Matéria & Sócios pareceristas \\
\hline 14 de julho & $\begin{array}{l}\text { I - sobre o cruzamento de } \\
\text { duas estradas de ferro }\end{array}$ & $\begin{array}{l}\text { Wallace Gama Cochrane; Januário de } \\
\text { Oliveira; Eduardo Klingelhoefer }\end{array}$ \\
\hline 17 de julho & $\begin{array}{l}\text { II - telégrafo das estradas de } \\
\text { ferro }\end{array}$ & $\begin{array}{c}\text { Mello Barreto; José Américo dos San- } \\
\text { tos e Aarão Reis }\end{array}$ \\
\hline 19 de julho & $\begin{array}{l}\text { III — reduçáo das tarifas das } \\
\text { estradas de ferro }\end{array}$ & $\begin{array}{c}\text { F. Mayrinck, Mello Barreto; Hercula- } \\
\text { no Penna }\end{array}$ \\
\hline 29 de agosto & $\begin{array}{l}\text { IV - sistema de garantia de } \\
\text { juros às empresas de estradas } \\
\text { de ferro }\end{array}$ & $\begin{array}{l}\text { Pedro Betim, A. M. Oliveira Bulhóes; } \\
\text { Wallace Cochrane }\end{array}$ \\
\hline 19 de julho & $\begin{array}{c}\mathrm{V} \text { - zonas privilegiadas das } \\
\text { estradas de ferro }\end{array}$ & $\begin{array}{c}\text { José Américo dos Santos e André } \\
\text { Gustavo Paulo de Frontin }\end{array}$ \\
\hline 29 de julho & $\begin{array}{c}\text { VI - plano geral da viação } \\
\text { férrea }\end{array}$ & $\begin{array}{l}\text { A. M. Oliveira Bulhóes, Firmo José } \\
\text { de Mello, Jorge Rademarker Gru- } \\
\text { newald }\end{array}$ \\
\hline 1 de agosto & $\begin{array}{c}\text { VII - determinaçáo do } \\
\text { coeficiente da resistência dos } \\
\text { trens }\end{array}$ & $\begin{array}{c}\text { Carlos Conrado de Niemeyer, Ray- } \\
\text { mundo Teixeira Belfort Roxo e Hen- } \\
\text { rique Hargreaves }\end{array}$ \\
\hline 8 de agosto & $\begin{array}{c}\text { VIII - revisão da lei de } \\
\text { desapropriaçáo para uso das } \\
\text { estradas de ferro }\end{array}$ & $\begin{array}{l}\text { Firmo José de Mello, Francisco Perei- } \\
\text { ra Passos e Paulo de Frontin }\end{array}$ \\
\hline 10 de agosto & IX — vias navegáveis do Brasil & $\begin{array}{l}\text { Jeronymo Moraes Jardim, Francisco } \\
\text { Pereira Passos, R. F. Belfort Roxo }\end{array}$ \\
\hline 10 de agosto & $\begin{array}{l}\mathrm{X} \text { - o regulamento de } 26 \mathrm{de} \\
\text { abril de } 1857 \text { sobre a polícia e } \\
\text { segurança das estradas de ferro }\end{array}$ & $\begin{array}{c}\text { Francisco Pereira Passos e Joaquim } \\
\text { M. R. Lisboa }\end{array}$ \\
\hline 14 de agosto & $\begin{array}{l}\text { XI —os impostos municipais } \\
\text { sobre os gêneros que se } \\
\text { servem das estradas de ferro } \\
\text { em demanda dos mercados } \\
\text { consumidores ou exportadores }\end{array}$ & $\begin{array}{l}\text { Domingos José Rodrigues, F. P. } \\
\text { Mayrinck e Luiz Bittencourt Sobri- } \\
\text { nho }\end{array}$ \\
\hline 22 de agosto & $\begin{array}{l}\text { XII — as bases gerais para } \\
\text { a descriminaçáo da receita } \\
\text { e despesa; movimento de } \\
\text { passageiros e mercadorias e } \\
\text { mais dados estatísticos do } \\
\text { tráfego das estradas de ferro }\end{array}$ & $\begin{array}{c}\text { Jorge Rademarker Grunewald, João } \\
\text { Carvalho Borges Junior e Álvaro Ro- } \\
\text { dovalho Marcondes dos Reis }\end{array}$ \\
\hline
\end{tabular}

Fonte: REIS, Aarão Leal de Carvalho (Org.). Primeiro congresso das estradas de ferro do Brasil. Archivos dos Trabalhos. Rio de Janeiro: Clube de Engenharia, 1882. ${ }^{25}$

\footnotetext{
${ }^{25}$ Apud MARINHO, Pedro Eduardo Mesquita de Monteiro. Ampliando o estado imperial: os engenheiros e a organização da cultura no Brasil oitocentista, 1874-1888, op. cit.
} 
Envolvidos intensamente na viabilização do "complexo econômico" que surgia, os engenheiros assim se organizavam, negociavam, disputavam e estabeleciam alianças no âmbito da sociedade civil, ${ }^{26}$ ao mesmo tempo que inscreviam agentes na sociedade política, com vista a realizar açóes particulares e salvaguardar os seus próprios interesses e os da classe que se vinculavam, quaisquer que fossem as fraçóes hegemônicas dentro dos complexos agroexportadores que conseguiam fazer girar, sob a sua órbita, a vida econômica do país.

No que diz respeito especificamente aos engenheiros que estamos analisando, a sua inserção profissional foi correlata a essa intensificação ferroviária. Dentre os diversos decretos e leis elaborados no âmbito de agências da sociedade política (como o Macop - Ministério da Agricultura, Comércio e Obras Públicas e Mivop — Ministério da Indústria, Viação e Obras Públicas), elencamos, nesse período, aqueles que versavam especificamente sobre questôes vinculadas às atividades profissionais dos engenheiros e que estiveram vinculados às formulaçóes e construção consensuais elaboradas pelos engenheiros do IPB e do Clube de Engenharia. ${ }^{27}$

${ }^{26}$ Como perspectiva teórica, adotamos a noção gramsciana de Estado ampliado, cuja formulação, em linhas gerais, toma como pressuposto a ideia de que este mesmo Estado se amplia e se torna mais complexo mediante a incorporação progressiva de quadros oriundos de "aparelhos privados de hegemonia". Desse modo, a partir da matriz gramsciana de "Estado ampliado", visto como uma relação social e dialética entre sociedade civil e sociedade política, consideram-se não somente seus aparelhos de coerção — que visam à dominação e a possibilitam —, mas, também, a sua capacidade de produzir e reproduzir uma direção moral, intelectual e, portanto, cultural, exercida por uma fração de classe ou grupo social sobre outras fraçóes ou grupos. As concepçôes do revolucionário italiano Antonio Gramsci privilegiaram as formas através das quais se assegura o predomínio de um grupo ou fração de classe sobre o conjunto da sociedade nacional inteira, exercido mediante as organizações privadas de hegemonia. O Estado é compreendido como "o organismo próprio de um grupo destinado a criar as condiçôes favoráveis à máxima expansão do próprio grupo”. O que garante a eficiência desse processo expansivo é não ser identificado como a concretização de interesses exclusivos dos grupos beneficiados, mas como expressão de toda a sociedade. A sociedade não consiste apenas num modo de produção garantido coercitivamente pelo "poder do Estado", mas também em hábitos de vida e pensamento, numa concepção de mundo amplamente difundida pela sociedade e na qual se inserem os costumes, a moral, o gosto popular, o senso comum, o folclore e também os princípios filosóficos e religiosos da maioria da população. E é esse modo de pensar e agir dos homens e dos governados que consiste no mais importante suporte da ordem constituída. A força plena é uma reserva para os momentos excepcionais, os momentos de crise. Normalmente, o domínio da classe ou fração de classe dominante se apoia sobre uma adesão dos governados ao tipo de sociedade em que vivem, isto é, sobre o consenso. Gramsci desloca a noçáo centáurica - meio homem, meio animal — do Príncipe, de Maquiavel — para o Estado, denominando-o como instituição composta de força e consenso, de dominação e hegemonia, de violência e civilização. Mas não se trata apenas de uma dualidade justaposta e, sim, de um processo orgânico complexo, sintetizando o Estado no conjunto formado pela sociedade política e sociedade civil, uma noção de "Estado ampliado". Tal perspectiva ajuda a pensar como os engenheiros brasileiros construíram suas práticas e representaçôes frente aos grupos organizados da sociedade civil aos quais estavam vinculados e, ainda, o que disputavam e como asseguravam sua presença nas diversas agências do Estado ampliado.

${ }^{27}$ De acordo com Sonia Mendonça, "o reconhecimento formal do estatuto de interlocutor legítimo conferido à [agremiação] se traduziria na infinidade de comissóes ministeriais a que a que ela seria instada a participar, bem como na atribuição de vagas a serem por ela preenchidas nos Conselhos" (MENDONÇA, Sonia Regina de. O ruralismo brasileiro (1888-1931). São Paulo: Hucitec, 1997, p. 56). 
Tabela 3

Legislação referente ao campo das atividades profissionais ligadas à Engenharia (1871-1905)

\begin{tabular}{|c|c|}
\hline Ramos e setores de atividades & Decretos 1874-1905 \\
\hline Estrada de ferro e transporte urbano & 91 \\
\hline Portos & 27 \\
\hline Navegação & 14 \\
\hline Construção Civil/Obras públicas Urbanas & 13 \\
\hline Telégrafos & 8 \\
\hline Ensino engenharia & 5 \\
\hline Registro de Patentes e Prop. Industrial & 4 \\
\hline Iluminação & 3 \\
\hline Regulamentação profissional & 2 \\
\hline Telefonia & 2 \\
\hline Obras contra a seca & 2 \\
\hline Engenho e açude & 2 \\
\hline Vocabulário técnico & 1 \\
\hline Total & $\mathbf{1 7 4}$ \\
\hline
\end{tabular}

Fonte: BRASIL. Coleção de leis e decisões do Império do Brasil. Rio de Janeiro: Imprensa Nacional, 1874-1889; BRASIL. Coleção das Leis da República: atos do poder executivo. Rio de Janeiro: Imprensa Nacional, 1942. ${ }^{28}$

Como é possível notar na tabela 3, a imensa maioria da legislação centrava-se nas estradas de ferro. De um total de 174 decretos, 91 são relativos ao setor (entendidas aí as concessóes a particulares ou empresas, a aprovação de estudos para viabilidade de novas estradas de ferro ou para sua ampliação, concessão de garantia de juros, aumento orçamentário, regulamentação de fiscalização de obras e funcionamento etc.). Ainda como parte do contexto do complexo agroexportador, na segunda posição há uma significativa concentração de decretos (27) ligados às atividades do setor portuário. Em terceiro lugar, estão os decretos relativos às concessóes às empresas de navegação, sobressaindo a reorganização da Companhia Lloyd Brasileiro.

Os vínculos que garantiam o destaque profissional, político e até mesmo empresarial, como já observamos, estiveram ligados primordialmente a esses setores. Claramente, e portanto, tinha atenção prioritária no atendimento para as políticas públicas, aquelas encaminhadas pelas agências no aparato governamental, com inscriçôes das frações agrárias exportadoras. Estava aí também o lócus profissional e político na sociedade política dos engenheiros civis, não apenas profissional, mas também como intelectual com organicidade para construir consensos da sociedade civil.

\footnotetext{
${ }^{28}$ Apud MARINHO, Pedro Eduardo Mesquita de Monteiro. Ampliando o estado imperial: os engenheiros e a organização da cultura no Brasil oitocentista, 1874-1888, op. cit.
} 
Dessa forma, há um expressivo contingente de leis que tratam das grandes obras públicas, tais como estradas de ferro, abastecimento de água, construção de habitaçóes populares e arrasamento de morros, todas as obras que se potencializavam com o crescimento populacional da Corte e demais províncias, e em que os engenheiros inseriam-se progressivamente. ${ }^{29}$

Os demais decretos e leis guardaram também alguma relação com aqueles ligados diretamente aos interesses das fraçóes agroexportadores. As linhas telegráficas, que, ao longo da segunda metade do século XIX, tenderam a acompanhar a construção das estradas de ferro, já haviam logrado a comunicação com a Europa e os Estados Unidos através de cabos submarinos, assim como já haviam coberto, até a década de 1886, cerca de 10 mil quilômetros de linhas estabelecendo ligaçóes com 182 estaçóes. Entretanto, a deficiência da cobertura telegráfica no território brasileiro deixaria inacessíveis as províncias de Mato Grosso, Goiás e Amazonas, todas sem comunicação direta com o restante do país. ${ }^{30}$

Além das regulamentações mencionadas, é perceptível, para as décadas em questão, um contingente ainda pequeno de decretos e leis distribuídos entre os ramos de construção civil de habitações populares (5); legislação regulamentando as Escolas de Engenharia (5); sobre a regulamentação dos registros de parente e de propriedade industrial (4), bem como o processo de regulamentação da transformação da iluminação pública a gás para o início da constituição de hidrelétricas e instalação do fornecimento de energia elétrica (4). E ainda há aqueles ramos que tiveram referências esporádicas, tais como a regulamentação profissional dos engenheiros, a constituição de um vocabulário de normas técnicas, a providência de obras contra as secas no Nordeste e o atendimento às demandas de obras nos açudes e engenhos.

Ressaltamos também que, embora tenham sido os anos de 1880 a 1890 o auge das construções ferroviárias, os engenheiros não estavam restritos à "engenharia ferroviária”. $\mathrm{Na}$ realidade, como sublinhado em outros momentos de nosso trabalho, o processo se iniciara rumo a uma ampliação dos espaços profissionais, empresariais e políticos, tanto na sociedade civil quanto na sociedade política. Exemplo dessa conjectura é o início de um conjunto de legislaçóes que apontava para o eixo urbano como campo de trabalho especializado e demais serviços que se instalariam ao longo da república, tais como os decretos que iniciam as concessóes de serviços de telefonia. A respeito deles, destacamos que Charles Paul Mackie, estadunidense integrante do Grupo Dirigente do Clube de Engenharia, e empresário com fortes ligações políticas, foi concessionário dos serviços de telefonia, benefício garantido após a sua aproximação da agremiação.

Consta de extensa literatura especializada que investiga o fim do império e a transformação das estradas de ferro na principal indústria brasileira ${ }^{31}$ do período, cuja característica

\footnotetext{
${ }^{29}$ MARINHO, Pedro Eduardo Mesquita de Monteiro. Engenharia imperial: o Instituto Politécnico Brasileiro (1862-1880), op. cit.

${ }^{30}$ MACIEL, Laura Antunes. Cultura e tecnologia: a constituição do serviço telegráfico no Brasil. Revista Brasileira de História, São Paulo, v. 21, n. 41, p. 133.

${ }^{31}$ BRITO, José do Nascimento. Meio século de estrada de ferro. Rio de Janeiro: Livraria São José, 1961;
} 
fundamental era a manutenção da monocultura de exportação do café. Todavia, ao mesmo tempo que seu traçado foi planejado a fim de garantir a produção e exportação do café, as ferrovias, em vários momentos distintos, também se destinaram a outros propósitos, tais como ao transporte de passageiros, de gêneros agrícolas e mercadorias diversas (algodão, açúcar, milho, sal etc.), de produtos importados (como o combustível para os próprios empreendimentos ferroviários), além de artigos para as famílias dos fazendeiros. Os mineiros de fora da Zona da Mata, por exemplo, conforme afirma Blasenheim, precisavam vender seus produtos de granja, fazendas e minas, ${ }^{32}$ assim como a mão de obra escrava fluminense, de acordo com Andrea Rabello, devia ser alimentada, sendo que parte dos produtos necessários, como farinha, feijão e toucinho, chegava através das estradas de ferro. ${ }^{33}$ Concomitante ao fato de que as linhas concentravam essas funçóes, elas conseguiam aproximar habitantes de diferentes regiōes e províncias, possibilitando a ligação e o estabelecimento de alianças entre grupos sociais e regionais distintos. Portanto, é preciso nos deter ao fato de que o advento ferroviário, iniciado na década de 1850, tinha em seu bojo aspectos que envolviam uma gama de interesses conexos e também diversos. Dentre os grupos e agentes implicados nesta indústria, encontravam-se os capitalistas estrangeiros (norte-americanos, franceses e, especialmente, ingleses), investidores e sócios das linhas (incluindo alguns fazendeiros), os proprietários nacionais das estradas de ferro, os grupos regionais proprietários das lavouras de café que disputavam espaço dentro do próprio complexo agroexportador, os proprietários das demais lavouras de menor importância para o comércio de exportação, além dos profissionais da engenharia que, em muitos casos, tornaram-se diretores das vias, concessionários dos ramais e implicados com a própria comercialização do café.

CARVALHO, Maria Alice Rezende de. O quinto século: André Rebouças e a construção do Brasil. Rio de Janeiro: Revan/IUPERJ-UCAM, 1998; DAVID, Eduardo Gonçalves. 127 anos de ferrovia. Rio de Janeiro: AENFER, 1985; DAVID, Eduardo Gonçalves. Estrada de Ferro Central do Brasil - a ferrovia e sua história. Rio de Janeiro: AENFER/AMUTREM, 1998; KANTINSKY, Júlio Roberto. Ferrovias nacionais. In: MOTOYAMA, Shozo (Org.). Tecnologia e industrialização no Brasil: uma perspectiva histórica. São Paulo: UNESP/CEETEPS, 1994; SAES, Flavio A. Marques de. As ferrovias de São Paulo, 1870-1940. São Paulo: Hucitec, 1981; SAES, Flavio A. Marques de. A grande empresa de serviços públicos na economia cafeeira, 1850-1930. São Paulo: Hucitec, 1986; AZEVEDO, Fernando de. Um trem corre para o oeste: estudo sobre a Noroeste e seu papel no sistema de viação nacional. Obras Completas v. XII, 2 ed. São Paulo: Melhoramentos, 1950; DEAN, Warren. A industrialização de São Paulo (1880-1945). São Paulo: Difel/ Edusp, 1971; GRAHAM, Richard. Grä-Bretanha e o início da modernização no Brasil (1850-1914). São Paulo: Brasiliense, 1973; LAMOUNIER, Maria Lúcia. Ferrovias, agricultura de exportação e mão de obra no Brasil no século XIX. História econômica \& História de empresas, v. III, n. 1, 2000, p. 43-76; TELLES, Pedro Carlos da Silva. História da Engenharia no Brasil - séculos XVI a XIX, v. 1, 2. ed. Rio de Janeiro: Clavero, 1994; VARGAS, Milton (Org.). História da técnica e da tecnologia no Brasil. Sáo Paulo: Unesp, 1994; SUMMERHILL, William. Order Against Progress: Government, Foreign Investment, and Railroads in Brazil, 1854-1913. Califórnia: Stanford University Press, 2003.

${ }^{32}$ BLASENHEIM, Peter L. As ferrovias de Minas Gerais no século XIX. In Locus: revista de história, Juiz de Fora, NHR/ EDUFJF, 1996, v. 2, n. 2, 1996, p. 81-110.

${ }^{33}$ RABELLO, Andrea Fernandes Considera Campagnac. Os caminhos de ferro da província do Rio de Janeiro. Ferrovias e café na $2^{\underline{a}}$ metade do século XIX, op. cit. 
Sendo assim, consideramos possível afirmar que, uma vez diagnosticada a relação entre engenheiros e as companhias de estradas de ferro com a fração hegemônica do complexo agroexportador cafeeiro, os agentes investigados — intelectuais orgânicos organizados na sociedade civil - estavam, num primeiro momento, estreitamente vinculados a tais fraçóes hegemônicas. Contudo, este "técnico modernizador" vivia um contexto histórico marcado por profundas e rápidas modificaçôes em níveis socioeconômico, político e cultural. Ora, as agitaçôes e contendas que incidiam sobre a sociedade como um todo, alicerçadas pela desagregação do império, atingiam em cheio os agentes em análise. No entanto, isso não significa que todos os engenheiros em questão levantassem bandeiras abolicionistas ou industrialistas. A complexidade que marca a transformação do regime - característica da década de 1880 — é também substância da complexidade da própria análise das questóes que eles defendiam. Tal aspecto apresenta-se como chave interpretativa importante para a compreensão, na análise realizada adiante, de quais interesses estavam implicados nos debates, além daqueles diretamente relacionados com a manutenção de sua posição e status profissional.

As Escolas de Engenharia, o Instituto Politécnico Brasileiro e, mais tarde, o Clube de Engenharia desempenhariam um papel de destaque, posto que emergiam como agências estratégicas da sociedade civil ao longo da segunda metade do século XIX, formadas por agentes detentores de prestígio, ascensão social e profissional. Dessa feita, o grupo de intelectuais orgânicos em questão constituía-se, aos poucos, como organizador da cultura, aqui entendida como solda da ação política e concepção do mundo. Ao mesmo tempo, com a conformação de seus interesses na sociedade civil e a sua representatividade junto aos aparelhos privados de hegemonia e a pressão por sua inscrição frente a determinados organismos da sociedade política ligadas às obras públicas, os elementos que integravam esse grupo tenderam a constituir um peso significativo nas relaçóes de força vigentes.

Uma vez que os dados primários levantados por pesquisa anterior ${ }^{34}$ revelam uma forte implicação dos engenheiros — em especial aqueles agremiados no Clube de Engenharia - com o incremento das estradas de ferro, buscaremos apresentar, em linhas gerais, como se configurou o processo de implantação das ferrovias no país. Contudo, é importante ressaltarmos que autores anteriormente realizadores de investigaçóes exaustivas sobre o tema identificaram grande dificuldade em desvendar suas trajetórias: em primeiro lugar por deficiência de dados. Em segundo, pelo intrincado processo de concessóes, encampações e privatizações, construções de linhas e de uma quase infinda multiplicidade de ramais, com investimentos de agentes diversos, detentores de capital privado nacional ou estrangeiro, e cujo controle dos governos provinciais e federal não obstacularizava a construção de linhas "cata café" de fazendeiros particulares. Enfim, um mapeamento histórico das estradas de ferro tornar-se-ia um trabalho à parte que excederia os objetivos deste.

\footnotetext{
${ }^{34}$ MARINHO, Pedro Eduardo Mesquita de Monteiro. Ampliando o estado imperial: os engenheiros e a organização da cultura no Brasil oitocentista, 1874-1888, op. cit.
} 
Por conseguinte, nossa intenção não é apresentar a história das estradas de ferro ou da Estrada de Ferro D. Pedro II, mas apenas alguns aspectos capazes de desvendar, posteriormente, as relaçóes estabelecidas entre os agentes do Clube de Engenharia, em sua primeira década de existência, e a indústria de ferrovias propriamente dita.

A partir do que aqui foi exposto, é fato que o campo de ação para engenheiros aumentou ao longo do século XIX. Em síntese, a engenharia, desde o final do século XVIII, particularmente em meados do século XIX, esteve presente nas grandes obras públicas e, especialmente, na construção de ferrovias.

Tomando como ponto de partida as primeiras estradas de ferro nacionais, construídas na segunda metade do século XIX, desenhou-se uma forte interação entre os interesses dos investidores e a iniciativa governamental. Tal processo constituiu-se através da concessão das áreas para as empresas, o estabelecimento de regras para a desapropriação dos terrenos marginais às linhas, a fixaçâo de taxas de juros, a isenção de impostos, inclusive no caso da eletrificação. Essa relação social tornou-se tão importante quanto os conhecimentos técnicos dos engenheiros envolvidos. ${ }^{35}$

As obras eram executadas pela aquisição de capital através de empréstimos ao mercado exterior garantidos pelo governo imperial. Nesse contexto, vale lembrar que as empresas que sofriam algum tipo de crise econômica eram encampadas pelo governo e que, de diferentes formas, o empreendimento ferroviário recebia investimentos do orçamento governamental.

$\mathrm{Na}$ época, as ferrovias eram consideradas verdadeiros símbolos de "progresso", já que encurtavam distâncias e transportavam as mercadorias destinadas a suprir o mercado externo, possibilitando a chegada de certos bens a lugares antes quase inatingíveis. Hobsbawm assinala que

a estrada de ferro, arrastando sua enorme serpente emplumada de fumaça, à velocidade do vento, através de países e continentes, com suas obras de engenharia, estaçôes e pontes formando um conjunto de construçóes que fazia as pirâmides do Egito e os aquedutos romanos e até mesmo a Grande Muralha da China empalidecerem de provincianismo, era o próprio símbolo do triunfo do homem. ${ }^{36}$

Pelo menos desde a primeira metade do século XIX, os dirigentes imperiais já vinham tentando formular uma lei que incentivasse a implantação, no país, de vias férreas. Em 1835, Antonio Paulino Limpo de Abreu, ministro da Justiça e interino do Ministério do Império, em companhia do então regente do império, Diogo Antonio Feijó, assinou decreto que concedia "a uma ou mais Companhias, que fizerem uma estrada de ferro da Capital do Império para as de Minas Gerais, Rio Grande do Sul, e Bahia, o privilégio exclusivo por

\footnotetext{
${ }^{35}$ Ibidem.

${ }^{36}$ HOBSBAWM, Eric. A era do capital. São Paulo: Paz e Terra, 1982, p. 61. 
espaço de 40 anos para o uso de carros para transporte de gêneros e passageiros" ${ }^{37}$ A proposta oferecida, que totalizaria uma extensão de mais de 5.500 quilômetros, ligando o Rio de Janeiro a Minas Gerais, Rio Grande do Sul à Bahia, aponta para o fato de que a formulação dos dirigentes do império fosse uma resposta ao impacto do uso da tração a vapor que já vinha sendo utilizada em vias fluviais do império brasileiro, bem como às repercussóes do impulso ferroviário na Inglaterra. Convertendo as "cinco léguas de estrada" de ferro, elas se constituiriam 33 quilômetros de construção anual. Para as possibilidades da época, tal meta demonstrava ser uma proposta irreal.

Em 1854, foi construída a primeira estrada de ferro brasileira, no Rio de Janeiro, por iniciativa do barão de Mauá, utilizando investimento e mão de obra inglesa. Nesse mesmo ano, constitui-se, a partir das pressóes dos produtores de café, a Companhia de Estradas de Ferro D. Pedro II, que seria responsável pela construção das interligaçôes entre Rio de Janeiro, São Paulo e Minas Gerais, a partir da capital. Para Graham,

A despeito da falta de entusiasmo inicial, os ingleses contribuíram grandemente para sua construçáo. Assim que a companhia foi organizada, levantou um empréstimo na Inglaterra, de mais de 1,5 milhóes de libras, com garantias dadas pelo governo brasileiro. $\mathrm{O}$ primeiro presidente da Companhia, Christiano Benedicto Ottoni — criticado pelos ingleses - teve que admitir que "sem esse empréstimo a ferrovia náo teria cruzado a cordilheira". Em 1871 e 1875, depois de a linha férrea se tornar efetivamente propriedade do governo, grandes empréstimos foram conseguidos em Londres para outras construçôes..$^{38}$

Da construção do primeiro trecho da estrada até sua inauguraçáo transcorreu-se um longo tempo dedicado à busca da melhor localização para transpor as serras, que são uma constante no cenário do estado do Rio de Janeiro. O melhor traçado indicava que se construísse um túnel próximo à cidade de Rodeio, atual Paulo de Frontin (RJ), encurtando assim o caminho até o porto do Rio. Em 1858, teve início a construção dessa estrada de ferro, que consistiu numa das mais significativas obras da engenharia ferroviária do país, superando os 412 metros de altura da Serra do Mar, com a realizaçáo de monumentais aterros, cortes e perfuraçóes de túneis, dentre eles o Túnel Grande (túnel 12), que possuía 2.245 metros de extensão e "261/8 palmos" de altura.

Na década de 1860, iniciava-se a formação da "malha ferroviária" paulista, com a formação em Londres da empresa The São Paulo Railway Company, construtora da estrada conhecida como "inglesa", cujo trajeto ia desde o porto de Santos até São Paulo e posteriormente até Jundiaí e Campinas, com 10\% do capital subscrito por Mauá e seus sócios, e o

\footnotetext{
${ }^{37}$ Decreto no 101 de 31 de outubro de 1835. FEIJÓ, Diogo Antonio. BRASIL. Coleção de Leis do Império do Brasil. 1835.

${ }^{38}$ GRAHAM, Richard. A Grã-Bretanha e o início da modernização do Brasil. São Paulo: Brasiliense, 1973, p. 60-61.
} 
restante, por capitalistas ingleses. O privilégio de zona que lhes fora concedido garantiu-lhes todo o escoamento de produtos agrícolas e minerais no trajeto entre São Paulo e Santos, tornando a exploração dessa ferrovia uma verdadeira mina de ouro. ${ }^{39}$

Desta maneira, num primeiro momento, as estradas de ferro foram construídas com a participação de engenheiros estrangeiros. Conforme a demanda em relação ao trabalho dos profissionais aumentava, criaram-se escolas para atender a essa nova categoria de profissionais que, aos poucos, constituía-se no Brasil. Dessa forma, em 1874, na primeira organização curricular da Escola Politécnica do Rio de Janeiro, instituiu-se a cadeira "Estradas Ordinárias, Estradas de Ferro, Pontes e Viadutos”, procurando suprir as necessidades de conhecimento técnico sobre esses assuntos. ${ }^{40} \mathrm{Na}$ década de 1880 , organizaram-se novas disciplinas de engenharia com a perspectiva de atender a um número crescente de engenheiros que atuavam nos projetos ferroviários e aprofundando a institucionalização.

Assim, em 29 de março de 1858, foi inaugurada a mais importante estrada de ferro para o império e, correlatamente, para a nascente engenharia civil. A Estrada de Ferro D. Pedro II que, de todos os empreendimentos ferroviários, é o que concentrou o maior número de dirigentes do Clube de Engenharia, iniciou suas atividades com trecho inicial de 47,21 km, da Estação da Corte a Queimados, no Rio de Janeiro. Surgiu com investimentos de capitais privados, no mesmo tempo e lugar da produção do café, garantindo, assim, grande redução nos custos dos transportes e dividendos para seus acionistas. Mediante cálculos feitos por Taunay, Sérgio Silva observou que a economia produzida foi cerca de $10 \%$ do preço do café na regiáo fluminense durante o período compreendido entre 1860 e 1868, uma vez que o custo do transporte por tropas de mulas era seis vezes maior que o ferroviário. ${ }^{41}$

\section{DIRETORES DA ESTRADA DE FERRO D. PEDRO II (1858-1889)}

29/03/1858 a 13/12/1865 — Christiano Benedicto Ottoni

14/12/1865 a 13/01/1869 — Bento José Ribeiro Sobragy

14/01/1869 a 14/02/1872 — Mariano Procópio Ferreira Lage

15/02/1872 a 11/04/1873 - Elisário Antonio dos Santos (barão de Angra)

16/04/1873 a 12/06/1876 — Bento José Ribeiro Sobragy

31/08/1876 a 22/06/1880 — Francisco Pereira Passos

\footnotetext{
${ }^{39}$ SEGNINI, Liliana R. Petrilli. Ferrovias e ferroviários: uma contribuição para a análise do poder disciplinar na empresa. São Paulo: Autores Associados/Cortez, 1982. p. 24.

${ }^{40}$ Em 1860 já apareciam referências curriculares relativas ao ensino sobre as ferrovias, embora menos sistemáticas (Cf. TELES, Pedro Silva. História da engenharia no Brasil - séculos XVI a XIX, v. 1, 2. ed. Rio de Janeiro: Clavero, 1994, v. 1, p. 471).

${ }^{41}$ SILVA, Sérgio. Expansão cafeeira e origens da indústria no Brasil. 7. ed., São Paulo: Alfa Omega, 1986. p. 51.
} 
06/09/1880 a 26/01/1884 - Herculano Veloso Ferreira Pena

20/02/1884 a 29/07/1884 — Miguel Noel Nascente Burnier

19/11/1884 a 30/11/1889 — José Ewbanck da Câmara

Fonte: DAVID, Eduardo Gonçalves. A ferrovia e sua história. Estrada de Ferro Central do Brasil. Rio de Janeiro: AEF/AAMT, 1998, p. 137. ${ }^{42}$

Embora a produção de café da Província do Rio de Janeiro tenha saltado de um milhão de sacas em 1835 para um milhão e meio em 1840, atingindo seu apogeu em 1882, com cerca de dois milhôes e seiscentas mil sacas, e apesar da garantia de juros e outros incentivos garantidos por lei, essa estrada de ferro não conseguiu acompanhar a significativa expansão da produção cafeeira. Onze anos foi o tempo de duração em operação sob regime de sociedade anônima e, assim, em 1865, a D. Pedro II foi encampada pelo governo imperial. Na época com pouco mais de cem quilômetros, essa ferrovia continuou a ser utilizada pelos fazendeiros como um poderoso instrumento de reduçáo de custos. Assim, expandiu cerca de cem quilômetros para aproximadamente três mil e quinhentos quilômetros chegando à província de São Paulo (no Brás em 1875), Minas Gerais (em Juiz de Fora, no ano de 1875 e, em Belo Horizonte, em 1895), ampliando suas linhas dentro da província do Rio de Janeiro. ${ }^{43}$

Essa ferrovia teve a sua concessão e privilégio de exploração autorizados pelo decreto número 4.914 de 1872.

O beneficiário da concessão foi o engenheiro Antonio Paulo de Melo Barreto e foi entáo montada a empresa sob a denominação Estrada de Ferro Leopoldina, com garantia de juros e subvençôes avalizadas pelo governo brasileiro, bem como de empréstimos feitos em Londres, iniciando a exploração em 1872 e a construção em 1873. Em 1878, para conseguir a completa construção das linhas da Estrada de Ferro Leopoldina, Melo Barreto contraiu o empréstimo, baseado em debêntures (os primeiros a serem lançados na Praça). ${ }^{44}$

A Estrada de Ferro Leopoldina foi a primeira ferrovia construída na província de Minas Gerais, em 1872, por concessão do governo imperial e iniciativa dos fazendeiros da Zona da

\footnotetext{
${ }^{42}$ Apud MARINHO, Pedro Eduardo Mesquita de Monteiro. Ampliando o estado imperial: os engenheiros e a organização da cultura no Brasil oitocentista, 1874-1888, op. cit.

${ }^{43}$ Guia geral das estradas de ferro e empresas de transportes com elas articuladas. Rio de Janeiro: Contadoria Geral dos Transportes, 1960.

${ }^{44}$ PAULA, Dilma Andrade de. Fim de linha. A extinção de ramais da Estrada de Ferro Leopoldina, 19551974. Tese (doutorado em História) — Universidade Federal Fluminense, Niterói, 2000, p. 86.
} 
Mata. Do período que vai de 1876 a 1890, a companhia recebeu autorização para construir e encampar uma série de ramais, dentre os quais Estrada de Ferro Norte de Minas, Estrada de Ferro Mauá e Estrada de Ferro Príncipe do Grão Pará. Todavia, em 1891, ela passará a ser administrada pela Companhia Geral de Estradas de Ferro, empresa fundada com objetivo de comprar, vender e custear estradas de ferro próprias e de terceiros. Esta, por sua vez, passa a ser administrada por ingleses em 1897. Um ano depois, é fundada a The Rio de Janeiro Northern Railway Company (Leopoldina Railway), responsável por todas as estradas de ferro e ramais da antiga Estrada de Ferro Leopoldina. Em meados do século XX, ela é encampada pelo governo federal.

De acordo com os dados primários levantados para as duas últimas décadas do período imperial, ${ }^{45}$ a maioria do grupo dirigente do Clube de Engenharia esteve à frente de Companhias de Estadas de Ferro, fossem elas de propriedade privada nacional ou estrangeira, ou administradas por intermédio de agências governamentais. Em geral, eles ocupavam os cargos de engenheiro civil, engenheiro chefe, engenheiro fiscal, chefe de serviço telegráfico, diretor, diretor técnico, presidente, engenheiro condutor, chefe de linhas, chefe de tração e consultor, para citar alguns exemplos. Alguns poucos aparecem, na documentaçáo analisada sobre o Clube de Engenharia, como fundadores e proprietários. Há também um número mais significativo de agentes cujos registros nos documentos indicam terem sido membros de comissóes para o estudo da viabilidade das linhas e de ramais.

As duas companhias onde se é possível encontrar um maior número de dirigentes da agremiação ocupando postos de trabalho e direção são, em primeiro lugar, a Estrada de Ferro Dom Pedro II, com vinte agentes e, em segundo, a Estrada de Ferro Leopoldina, com seis. Por esse motivo, acreditamos ser relevante estabelecer algumas análises sobre os agentes que estiveram vinculados, de alguma maneira, a essas duas ferrovias, no caso do presente artigo, particularmente a EFDPII.

\section{Estrada de Ferro D. Pedro II}

Participaram do planejamento, da construção e da direção da EFDPII vários membros do Clube de Engenharia. Dentre aqueles que compuseram o quadro de dirigentes da agremiação, e que ocuparam o cargo de Diretor da EFDPII, estavam:

\footnotetext{
${ }^{45}$ MARINHO, Pedro Eduardo Mesquita de Monteiro. Ampliando o estado imperial: os engenheiros e a organização da cultura no Brasil oitocentista, 1874-1888, op. cit.
} 
Tabela 4

Diretores da EFDPII (1876-1889)

\begin{tabular}{|c|c|}
\hline 1876 a 1880 & Francisco Pereira Passos \\
\hline 1880 a 1884 & Herculano Veloso Ferreira Pena \\
\hline 1884 a 1889 & José Ewbanck da Câmara \\
\hline
\end{tabular}

Fonte: DAVID, Eduardo Gonçalves. A ferrovia e sua história. Estrada de Ferro Central do Brasil. Rio de Janeiro: AENFER, $1998 .{ }^{46}$

Após o golpe republicano, outros membros do Clube ascenderam à direção dessa ferrovia, que passou a ser chamada Estrada de Ferro Central do Brasil. De 1889 até a década de 20 do século XX, exerceram o cargo de “diretores” (ainda que, segundo Eduardo Gonçalves David, ${ }^{47}$ não tenha sido sempre essa denominação) João Chrockatt de Sá Pereira de Castro (1891), Jerônimo Rodrigues de Morais Jardim (de 1894 a 1896), André Gustavo Paulo de Frontin (de 1896 a 1897 e de 1910 a 1914), Francisco Pereira Passos (de 1897 a 1899), Gustavo Adolfo da Silveira (de 1900 a 1901), Gabriel Emiliano Osório de Almeida (de 1903 a 1906) e Aarão Leal de Carvalho Reis (de 1906 a 1910).

Portanto, os membros do Clube prevaleciam como diretores na última década do século XIX e início do XX. Possivelmente, sua perpetuação após a mudança do regime político - e, portanto, fração dirigente — indica que tais agentes conseguiram manter prestígio junto à correlação de forças que construiu a república, pelo menos em relação àqueles diretamente envolvidos na administração de vias férreas. Uma das possibilidades aventadas é terem conseguido consolidar agências no Ministério de Obras Públicas e por sua condição indispensável técnico-científica constituírem-se com profissionais imprescindíveis. ${ }^{48}$ Claro está também que alguns desses engenheiros já antecipavam a sua discordância para com a direção do bloco no poder do império. Para Aarão Reis, por exemplo, a continuidade na sociedade política deve ter sido mais confortável do que para outros agentes.

Além dos citados, esteve ligado à EFDPII Antonio Maria de Oliveira Bulhóes, ocupando o cargo de engenheiro chefe na década de 1850 e início da década 1860. João Chrockatt de Sá Pereira de Castro, mencionado anteriormente como um dos diretores do período republicano, também foi engenheiro fiscal da empresa em 1880. Desse modo, é possível concluir que o primeiro vinculou-se à empresa antes e o segundo, depois de sua encampação pelos dirigentes do governo imperial, ocorrida em 1865, conforme sublinhado anteriormente. Além do vínculo comum a essa empresa, ambos os agentes estiveram também imbricados, em

\footnotetext{
${ }^{46}$ Apud Ibidem.

${ }^{47}$ DAVID, Eduardo Gonçalves. A ferrovia e sua história. Estrada de Ferro Central do Brasil, op. cit.

${ }^{48}$ MARINHO, Pedro Eduardo Mesquita de Monteiro. Ampliando o estado imperial: os engenheiros e a organização da cultura no Brasil oitocentista, 1874-1888, op. cit. MARINHO, Pedro. Porta-vozes em uma era de incertezas: o Clube de Engenharia e a concepção de uma Inspetoria Geral das Estradas de Ferro, op. cit.
} 
momentos distintos, à sociedade política, sendo que cada um representou o que podemos deduzir como duas "geraçôes" do quadro dirigente do Clube de Engenharia. O primeiro esteve ligado à formulação da Inspetoria de Obras Públicas ainda durante o império; o segundo, à mesma agência, mas já no período da república. ${ }^{49}$ Malgrado as distintas gerações, ambos tinham em comum em seu currículo o fato de terem ocupado um após o outro a presidência do Clube de Engenharia e, em um mesmo momento, terem pertencido ao Conselho Diretor (1899-1900). Essa questâo, que se repetirá em relação a outros agentes, pode indicar a existência de um nexo contínuo entre a agremiação que buscamos investigar e ao Estado em sentido restrito, ou seja, uma ligação intrínseca entre os agentes do Clube de Engenharia organizados na sociedade civil e o seu correlato aparelhamento na sociedade política. ${ }^{50}$

Dentre os ramais ligados à EFDPII, incluímos a Linha Auxiliar até o Vale do Paraíba no Rio de Janeiro, que correspondia à antiga Companhia Melhoramentos do Brasil, servindo à região de plantação agrícola e cafeicultora. Essa ferrovia foi incorporada pela E. F. Central do Brasil (antiga EFDPII) em 1903. De acordo com os dados levantados, Francisco de Paula Bicalho, Carlos Conrado de Niemeyer e André Gustavo Paulo de Frontin se dedicaram juntos à Comissáo de Estudos do Macop - Ministério da Agricultura, Comércio e Obras Públicas — para a viabilizaçáo da obra em 1883.

Niemeyer e Frontin eram naturais do Rio de Janeiro, enquanto Francisco de Paula Bicalho era mineiro. Os três ingressaram no Clube de Engenharia nos primeiros anos de sua existência (entre 1880 e 1882; portanto, já estavam associados à agremiaçáo quando foi organizada a comissão mencionada, embora só Niemeyer ocupasse cargo na diretoria, à época). Todos também foram membros do Conselho Diretor em períodos diversos e se encontraram neste mesmo Conselho no início do século XX.

Frontin, que passou a ocupar cargos na diretoria do Clube em 1886, reservou a década de 1880 para as suas funçôes de dirigente da agremiação, outras relacionadas com as atividades para a EFDPII e o desempenho de atividades acadêmicas. Niemeyer e Bicalho, por sua vez, no período em que trabalharam para a mesma companhia, estavam inseridos em outras empresas e agências, exercendo funçôes diversas.

Antes de aderir ao projeto da Linha Auxiliar, Francisco Bicalho, que já acumulara vasta experiência em atividades ligadas às estradas de ferro exercidas na década de 1870, desempenhou na entrada dos anos 1880 a função de 1o engenheiro da Empresa de Obras Públicas do Abastecimento d'água do Rio de Janeiro (1878-1880) e, em meados da década, foi diretor da Estrada de Ferro Rio D’Ouro (1885). Ainda que tenha sido admitido em 1881 como membro do Clube, só passou a ocupar cargos na diretoria em 1888, como membro do Con-

\footnotetext{
${ }^{49}$ MARINHO, Pedro. Porta-vozes em uma era de incertezas: o Clube de Engenharia e a concepção de uma Inspetoria Geral das Estradas de Ferro, op. cit. p. 170-183.

${ }^{50}$ MARINHO, Pedro Eduardo Mesquita de Monteiro. Ampliando o estado imperial: os engenheiros e a organização da cultura no Brasil oitocentista, 1874-1888, op. cit.
} 
selho Diretor, portanto, quando já havia estabelecido uma carreira sólida nas atividades de engenharia voltadas para estradas de ferro e obras públicas.

Carlos Conrado de Niemeyer, por sua vez, já havia trabalhado junto a outras atividades na própria EFDPII em décadas anteriores. No decorrer do período em que esteve ligado às atividades diretamente relacionadas com a Comissão de Estudos do Macop para viabilizar a obra da ferrovia, dedicou-se a duas outras funçóes. Integrou o Conselho Diretor do Clube de Engenharia (no período que vai de 1881 a 1904, à exceção de alguns poucos mandatos), foi secretário da Seção de Comércio e Meios de Transporte (Sain — Sociedade Auxiliadora da Indústria Nacional) em 1885 e desempenhou a função de engenheiro chefe da Locomoçáo de EFDPII/Macop de 1876 a 1890. Os três agentes, nesse período, formavam uma tríade importante: o primeiro era recém-formado e vinculado a obras públicas de estradas de ferro e a atividades acadêmicas; o segundo, dedicado a agências das sociedades política e civil também ligadas a obras públicas e ferrovias; e o terceiro, fundador do Clube de Engenharia, inscrito na sociedade política e representante de uma agência ligada ao nascente grupo de industriais. Contudo, o que mais chama a atenção é a inscrição de cada um deles na sociedade política nas décadas que se seguiram à república, especialmente no caso de Francisco Bicalho e Paulo de Frontin. Bicalho, por exemplo, atuou como:

1893-1895 — chefe da construção da Alfândega de Juiz de Fora (MG), indicado pelo governo mineiro.

1895-1898 — chefe da Comissão construtora da cidade Belo Horizonte (MG).

1901 - Designado pelo governo federal para transferir a ferrovia para a Companhia Western (Estrada de ferro Recife a São Francisco).

1901 - inspetor geral das Obras Públicas da Capital Federal.

1903 - diretor geral da Comissão Construtora da Avenida Central, nomeado pelo ministro Lauro Müller (juntamente com Paulo de Frontin e Gabriel Osório de Almeida).

1903-1907 - diretor técnico da Comissão Fiscal e Administrativa das Obras (MvopMinistério da Viação e Obras Públicas) para o Porto do Rio de Janeiro (presidida por Lauro Müller e integrada por Paulo de Frontin, Gabriel Osório de Almeida, José Freire Parreiras Horta, Domingos Sérgio de Sabóia e Silva e Manuel Maria de Carvalho).

1906 - engenheiro civil da Comissão para estudo dos diques da ilha das Cobras do Rio de Janeiro.

E Frontin foi, durante toda a chamada Primeira República:

1896-1897 — diretor da EFCB.

1903 - diretor geral da Comissão Construtora da Avenida Central, nomeado pelo ministro Lauro Müller, juntamente com Francisco Bicalho e Gabriel Osório de Almeida. 
1903-1907 — diretor técnico da Comissão Fiscal e Administrativa das Obras do Porto do RJ - Mvop (presidida por Lauro Müller e integrada por Francisco Bicalho, Gabriel Osório de Almeida, José Freire Parreiras Horta, Domingos Sérgio de Sabóia e Silva e Manuel Maria de Carvalho).

1907-1908 - engenheiro chefe e organizador da Repartição de Fiscalização das Estradas de Ferro Federais.

1910-1914 — diretor da EFCB.

1912 - membro do Conselho Superior de Ensino.

1913-1914 - engenheiro-chefe da EFCB — Duplicação do trecho da Serra do Mar.

1915-1930 - diretor da EFCB.

1917 — senador eleito Distrito Federal.

1918 — senador eleito Distrito Federal.

1919 - deputado do Distrito Federal.

1919 - prefeito nomeado do Distrito Federal (pelo decreto de 22/01/1919).

Niemeyer, por sua vez e já na primeira década da república, seria:

1907 — engenheiro chefe de Seção de Estatística da Repartição Federal de Fiscalização das Estradas de Ferro.

Aarão Leal de Carvalho Reis, natural da província do Pará, e o recém-formado Amarílio Olinda de Vasconcellos, de Alagoas, foram chefes do Serviço Telegráfico da ferrovia E. F. D. Pedro II no mesmo período, entre 1881 e 1885. Da mesma forma, exerceram, na mesma década, funções na sociedade política. Vasconcellos foi engenheiro chefe de Diretoria de Obras Públicas - Macop, em 1886. Reis foi diretor de Obras Civis no Ministério da Marinha (entre 1887 e 1889) e diretor geral do Mivop (Ministério da Indústria, Viaçáo e Obras Públicas), no período compreendido entre 1889 e 1890. Na década de 1880, Reis foi ainda membro do Conselho Diretor do Clube, $3^{\circ}$ secretário do $1^{\circ}$ Congresso de Estradas de Estradas de Ferro de 1882 e sócio da Associação de Auxílios Mútuos dos Empregados da EFDPII. Vasconcellos ingressou, em 1885, na diretoria do Clube, ocupando uma vaga do Conselho Diretor, ficando o mandato de 1885 a 1886, mesmo período em que era do Macop. Todavia, desses dois agentes do grupo dirigente do Clube, observamos que apenas Aarão Reis teve ascendência expressiva na sociedade política após a república, mostrando-se um agente estratégico nos quadros da agremiação. Segundo as fontes consultadas, Aarão Reis atuou como:

1889-1890 - diretor geral do Mivop.

1890 - conselheiro do Mivop.

1891-1893 — engenheiro chefe da E. F. Elétrica da Tijuca (RJ). 
1892 - E. F. Melhoramentos no Brasil/Linha Auxiliar da Central do Brasil (Proj. Const.).

1892-1893 — chefe da Comissão de Estudos das localidades indicadas para a nova capital de Minas Gerais, Belo Horizonte, a convite de Afonso Pena.

1894-1895 — organizador e diretor geral dos Trabalhos da Construção da cidade Belo Horizonte.

1895 - diretor geral dos Correios da República.

1896-1897 — diretor da EFCB.

1906-1910 - diretor da EFCB.

1911 - suplente de deputado Federal do Estado do Pará.

1913-1918 — inspetor geral, Ifocs-Mvop

1918 - consultor técnico - Tavares de Lira, Mvop.

1927-1929 — deputado federal do estado do Pará.

Antonio Augusto Fernandes Pinheiro, fluminense, foi, em 1873 e 1876, 1o engenheiro civil do Prolongamento Alagoinhas a Juazeiro (BA) da EFDPII. Podemos afirmar que esse agente, semelhante a Carlos Conrado de Niemeyer, dentre outros, foi um dos representantes industriais que compunham o quadro de dirigentes do Clube de Engenharia. Sócio efetivo IPB e do Clube, era também sócio honorário da Associação Industrial e presidente da Seção de Indústria Fabril (Sain) de 1880 a 1885 e membro da Comissão Exposição da Indústria Nacional de 1881 a 1882. Além disso, foi também idealizador e presidente do $1^{\circ}$ Congresso de Estradas de Ferro, em 1882. Sua inserção nas agências ligadas aos industriais se deu concomitante ao seu ingresso no Clube e posterior à sua passagem pelas obras de ferrovias, onde desempenhava a função de engenheiro.

O gaúcho José Ewbank da Camara foi, em 1881, engenheiro chefe das Construções da Companhia em questáo e seu diretor entre 1884-1889, como referido anteriormente. Membro do IPB até 1889, fundador e vice-presidente do Clube no período compreendido entre 1887 e 1888, foi engenheiro consultor do Macop e, na década de 1880, juntamente com Niemeyer e Fernandes Pinheiro, fazia parte da Sain (era presidente da Seção de Estatística Industrial de 1885). Antes de suas funçôes na EFDPII, havia trabalhado em outras obras ligadas a vias férreas.

Antonio Maria de Oliveira Bulhôes foi um nome de destaque no Clube, tendo sido presidente em três mandatos e vice-presidente em um. $\mathrm{O}$ início de sua trajetória profissional data da década de 1850, quando fez os estudos preliminares para Linha Serra do Mar da EFDPII, em 1856. Entre as décadas de 1850 e 1870, participou de vários projetos como engenheiro civil dentro do Macop. Em 1882, participou do $1^{\circ}$ Congresso de Estradas de Ferro como $1^{\circ}$ vice- presidente e chefe da Comissão do Plano Geral da Viação. Em sua trajetória, encontra-se ainda a função de inspetor geral de Obras Públicas. Em 1887, compôs a comissão para 
estudo do relatório "Saneamento e prolongamento do Canal do Mangue do Rio de Janeiro do Clube de Engenharia”, juntamente com outros quatro dirigentes da agência em questão: Jorge Rademaker, Jerônimo de Moraes Jardim, Antonio Marques Baptista Leão e Frederico Liberalli.

Estes três últimos agentes apresentados (Antonio Augusto Fernandes Pinheiro, José Ewbank da Camara e Antonio Maria de Oliveira Bulhóes), ainda que reservem algumas particularidades, tiveram trajetórias profissionais semelhantes, no que diz respeito às empresas e agências as quais se filiaram. Os três se dedicaram a atividades relacionadas com as obras públicas, sobretudo aquelas vinculadas às estradas de ferro e estiveram ligados ao Macop por meio de comissóes, como engenheiros consultores ou inspetores de obras públicas. Parece importante destacar o fato de que Fernandes Pinheiro e Ewbank da Camara, que compunham uma mesma geração do Clube, estiveram, na mesma época, ligados à Sain em setores distintos: Indústria Fabril e Estatística Industrial, respectivamente.

De acordo com os registros dos documentos do Clube de Engenharia, Jerônimo Rodrigues de Morais Jardim, goiano, foi diretor da Companhia EFDPII entre 1894 e 1896, período posterior à passagem de Bulhóes pela empresa. Sócio efetivo do IPB e integrante do Conselho Diretor do Clube de Engenharia por oito mandatos (o primeiro em 1881 e o último terminado em 1893), foi suplente do Conselho Diretor e $1^{\circ}$ - vice-presidente entre 1893 e 1896. Além de ter pertencido dentro do Clube à Comissão para estudo do relatório de Saneamento e Prolongamento do Canal do Mangue, como dito anteriormente, juntou-se a Gabriel Osório de Almeida, em 1890, para elaboração do Plano de Viação realizado pelo Congresso de Estradas de Ferro em 1882. Foi 1o secretário deste $1^{\circ}$ Congresso de Estradas de Ferro e recebeu várias comendas, dentre as quais, Ordem de Cristo e Ordem da Rosa. Na década de 1870, inscreveu-se em diversas agências da sociedade política. Inclusive, é possível afirmar que Morais Jardim foi um dos quadros de maior destaque da agência por sua ascendência na sociedade política.

Foi engenheiro civil da Inspetoria Geral das Obras Públicas da Corte do Macop (1870). Fez parte de Comissóes do Macop (1875) e Comissóes do Ministério da Guerra (1875), foi engenheiro civil da Comissão Plano de Melhoramentos do Rio de Janeiro, foi do Ministério do Império (1874-1876), engenheiro chefe de abastecimento d'água RJ (1875). Inspetor Geral de Obras Públicas da Inspetoria Geral das Obras Públicas da Corte do Macop de 1874 a 1880. Além disso, ocupou cargos no Executivo e no Legislativo como deputado da província de Goiás (1879/1881/1884) e presidente da Província do Ceará (1889). Na última década do século, portanto, já na Primeira República, exerceu a função de chefe da Comissão para elaboração do Plano de Viação (junto a Gabriel Osório de Almeida, em 1890) e foi ministro do Mivop (1898). O agente, portanto, atravessou o fim do império e início da república como agente da sociedade civil e sociedade política nos dois períodos, inclusive se mantendo no Ministério de Obras Públicas — Mivop — mesmo depois de instaurada a república. 
Jorge Rademaker Grunewald, fundador do Clube e membro do Conselho Diretor por três mandatos (1886-1887; 1887-1888; 1893-1896), esteve na Companhia EFDPII em três momentos distintos: como chefe de seção em 1869, participou do projeto do novo prédio da Estação do Campo, em 1870 e, por fim, foi engenheiro chefe de Tráfego em 1876. Ao contrário dos nomes citados até o momento, não foram encontradas informaçôes desse agente exercendo funções em outras companhias de estradas de ferro.

Conrado Jacob de Niemeyer, fundador benemérito do Clube de Engenharia, foi desenhista e fiel de armazém da EFDPII até 1863 (Macop). Foi tesoureiro do Clube durante todo o período em análise, estendendo-se até 1904, à exceção de um ano, em que integrou o Conselho Diretor. Niemeyer, que não era engenheiro de formação, costumava ocupar cargos administrativos e/ou financeiros nas empresas, tais como de diretor e tesoureiro da Empresa Industrial de Melhoramentos no Brasil, em 1893, diretor da Moinho Fluminense e membro do Conselho Fiscal da Companhia de Carris Jardim Botânico (ambos sem informaçóes de datas). Na primeira década que se seguiu logo ao fim do império, o nome desse agente aparece como empresário. Em 1890, era proprietário e diretor da Empresa Comercial Soares \& Niemeyer; em 1893, diretor e tesoureiro da Empresa Industrial de Melhoramentos no Brasil; e, em 1917, fundador/sócio da Companhia Brasileira Carbonífera de Araranguá, em Santa Catarina.

Firmo José de Mello foi engenheiro chefe da ferrovia em 1873. Teve uma passagem rápida pela diretoria do Clube - foi membro do Conselho Diretor em um só mandato, de 1882 a 1883, mesmo período em que foi 2o vice-presidente do 1o Congresso de Estradas de Ferro do Brasil, em 1882. Trabalhou em outras três companhias de estradas de ferro e, tempo depois, mais especificamente em 1886, integrou a Macop como engenheiro chefe da $2^{a}$ Seção.

Francisco Pereira Passos, natural de Piraí, estado do Rio de Janeiro, foi diretor da Companhia EFDPII entre 1876 e 1880 e entre 1897-1899 (nesse período, já denominada Estrada de Ferro Central do Brasil). Antes dessa atividade, foi engenheiro civil da Comissão Plano de Melhoramentos Rio de Janeiro do Ministério do Império (1874-1876) e participou da Comissão de Elaboração do Vocabulário Técnico de Engenharia (1876). Sua trajetória na diretoria do Clube começou em 1881, como vice-presidente, cargo que ocupou até 1883. Logo depois, integrou o Conselho Diretor, onde foi membro por três mandatos não consecutivos. Além de ter se tornado empresário na República, foi diretor da EFCB entre 1897 e 1899, como informado anteriormente, e prefeito do Rio de Janeiro entre 1903-1906, mesmo período em que desempenhou a função de engenheiro chefe das obras da Avenida Central.

Gabriel Emiliano Osório de Almeida, antes de se associar ao Clube de Engenharia, em 1891, já havia trabalhado para a EFDPII (1888), para outras duas companhias de vias férreas (1888) e na Superintendência de Obras Públicas do Estado de São Paulo (1890). Seu ingresso no Clube ocorreu um ano após a sua participação, em 1890, em uma Comissão para elabo- 
ração de um Plano de Viação, constituída por Jerônimo de Moraes Jardim. No mesmo ano em que ingressou na agremiaçáo, foi consultor técnico do Ministério da Indústria, Viaçáo e Obras Públicas. Ao mesmo tempo que desempenhava atividades em agências do governo e em empresas de estradas de ferro, foi diretor, presidente e empreiteiro de empresas importantes, tais como a Companhia Docas de Santos e o Lloyd Brasileiro. É possível perceber que não foi exclusivamente a associação dos engenheiros que inscreveu esse agente na sociedade política. Contudo, com o advento da república, Osório de Almeida consolidou ainda mais a sua posição dentro de agências da sociedade política, através da ocupação de cargos diversos, tais como:

1903 - diretor geral dos Telégrafos.

1903-1906 — diretor da EFCB.

1903-1907 — diretor técnico da Comissão Fiscal e Administrativa das Obras do Porto do Rio de Janeiro - Ministério da Viação e Obras Públicas (presidida por Lauro Müller e integrada por Paulo de Frontin, Francisco Bicalho, José Freire Parreiras Horta, Domingos Sérgio de Sabóia e Silva e Manuel Maria de Carvalho).

1911-1913 - presidente do Conselho Municipal da Capital Federal.

1913 - árbitro do governo "nas questóes que se necessitarem" da Companhia do Porto do Rio de Janeiro.

1913-1916 — membro do Conselho Municipal do Rio de Janeiro.

João Teixeira Soares, mineiro, foi engenheiro residente designado para os estudos do Ramal Sapopemba a Santa Cruz entre 1876 e 1882 e foi engenheiro civil da mesma EFDPII - Macop em 1872. Ex-sócio do IPB, fundador e sócio vitalício benemérito do Clube, membro do Conselho Diretor por seis mandatos distintos, sendo o primeiro em 1881 e o último terminado em 1902. Foi também presidente no mandato de 1899 e 1900. Trabalhou em várias companhias de vias férreas nas décadas de 1880 e 1890. Sua trajetória foi marcadamente empresarial. De 1882 a 1920, pelo menos, Soares foi presidente de quatro firmas distintas: Lloyd Nacional, Empresa Soares \& Cia Ltda., Companhia Cantareira e Viação Fluminense e Estrada de Ferro Bauru a Itapura (EF Noroeste do Brasil). No mesmo período, foi proprietário da empresa Compagnie Chemins de Fer Sud Ouest Brésiliens. Nas décadas de 1870 e 1880, foi engenheiro de várias companhias de estradas de ferro, de capital privado ou via Macop, além da participação em comissōes para realização de obras públicas, como a do canal de Macaé a Campos (com Francisco de Paula Bicalho). No período republicano, foi engenheiro chefe da Comissão de Estudos e Saneamento da Baixada Fluminense e membro da Comissão de Elaboraçáo do Plano Regional de Viação de Minas Gerais.

E por último, além dos citados, tiveram vínculo com a EFDPII Eduardo Mendes Limoeiro (1872), Herculano Velloso Ferreira Penna (de 1880 a 1884), João Raymundo Duarte (1879) e Miran Latif (de 1884 a 1889). 


\section{Considerações finais}

Entre as fraçóes dominantes do Brasil oitocentista prevalecia a hegemonia de uma concepçáo do mundo dimensionada, em meio a outras matrizes, pelas várias mudanças que ocorriam no ocidente europeu. Ao mesmo tempo, no próprio contexto brasileiro elaboravam-se novas formas concretas de inserção em um mundo capitalista. De um modo geral, conquanto náo de forma homogênea, seus intelectuais buscavam vincular-se aos "valores científicos" predominantes e partilhavam a perspectiva de construir uma "imagem civilizada e moderna" do império brasileiro no exterior. Desta maneira, por intermédio da construção de uma referência profissional, os engenheiros brasileiros logravam vincular o seu lugar social dentro desse contexto dinâmico. Sua representação da ideia de "progresso" não era apenas um artifício retórico e superficial, mas uma real construção de identidade profissional alicerçada na concepção de que o Brasil devia a estes agentes a possibilidade de atingir a "civilização". Norteando tais formulaçóes, essas noções elaboravam-se por meio de duas faces interligadas: as transformaçóes internas da sociedade europeia e a expansão e dominação externas sobre os povos e territórios considerados "atrasados", "exóticos" e "naturalizados".

No Brasil imperial, grandes obras de construção civil exigiam, ao longo da segunda metade do século XIX, soluçóes técnicas para problemas complexos e inter-relacionados com a infraestrutura da nação. Para equacionar tais questóes, os engenheiros civis brasileiros, representados por sua agremiação — o Clube de Engenharia - e representantes de uma área profissional recém-institucionalizada, recebiam uma formação acadêmica que os preparava a exercer atividades profissionais bem amplas. Ademais, apreendiam conhecimentos específicos voltados para o domínio de quase todas as etapas de um mesmo ramo de produçáo, como no caso das estradas de ferro, junto às quais tais agentes se envolviam na elaboração, organização, construção e na própria fiscalização das obras. Dessa forma, o acesso ao campo de especialização na formulação de projetos e construção de grandes obras para a viabilização de vias férreas seria facilitado com o suporte da atualização dos conhecimentos necessários para a sua atuação profissional. $\mathrm{O}$ motivo primeiro de todo esse interesse na formação de agentes aptos à indústria ferroviária era, certamente, o aperfeiçoamento dos serviços de infraestrutura que começavam a ser privilegiados por amplos grupos sociais ligados ao poder decisório do aparelho governamental do país, com o propósito de solucionar problemas que preocupavam as fraçôes agroexportadoras dominantes, especialmente aqueles ligados à viabilização do escoamento da produção e à resolução sobre a questáo da mão de obra. 


\section{Referências bibliográficas}

AZEVEDO, Fernando de. Um trem corre para o oeste: estudo sobre a Noroeste e seu papel no sistema de viação nacional. Obras Completas v. XII, 2. ed. São Paulo: Melhoramentos, 1950.

BLASENHEIM, Peter L. As ferrovias de Minas Gerais no século XIX. In Locus: revista de história. Juiz de Fora, NHR/EDUFJF, v. 2, n. 2, 1996.

BRITO, José do Nascimento. Meio século de estrada de ferro. Rio de Janeiro: Livraria São José, 1961.

CARVALHO, Delgado apud SILVA, Sergio. Expansão cafeeira e origens da indístria no Brasil. 5. ed. São Paulo: Alfa-Omega, 1981.

CARVALHO, Maria Alice Rezende de. O quinto século: André Rebouças e a construção do Brasil. Rio de Janeiro: Revan/IUPERJ-UCAM, 1998.

COSTA, Emilia Viotti da. Da senzala à colônia. São Paulo: Unesp, 1998.

DAVID, Eduardo Gonçalves. 127 anos de ferrovia. Rio de Janeiro: Aenfer, 1985.

. A ferrovia e sua história. Estrada de Ferro Central do Brasil. Rio de Janeiro: Aenfer, 1998.

. Estrada de Ferro Central do Brasil - a ferrovia e sua história. Rio de Janeiro: Aenfer/ Amutrem, 1998.

DEAN, Warren. A industrialização de São Paulo (1880-1945). São Paulo: Difel/Edusp, 1971.

FAORO, Raymundo. A questão nacional: a modernização. Estudos Avançados, v. 6, n. 1, p. 7-22, 1992.

FEIJÓ, Diogo Antonio. BRASIL. Coleção de Leis do Império do Brasil. 1835.

GRAHAM, Richard. Grã-Bretanha e o início da modernização no Brasil (1850-1914). São Paulo: Brasiliense, 1973.

Guia geral das estradas de ferro e empresas de transportes com elas articuladas. Rio de Janeiro: Contadoria Geral dos Transportes, 1960.

HOBSBAWM, Eric. A era do capital. São Paulo: Paz e Terra, 1982.

KANTINSKY, Júlio Roberto. Ferrovias nacionais. In: MOTOYAMA, Shozo (Org.). Tecnologia e industrialização no Brasil: uma perspectiva histórica. São Paulo: Unesp/Ceeteps, 1994. LAMOUNIER, Maria Lúcia. Ferrovias, agricultura de exportação e mão de obra no Brasil no século XIX. História econômica \& História de empresas. Rio de Janeiro, v. III, n. 1, 2000. Disponível em: <http://www.revistaabphe.uff.br/index.php?journal=rabphe\&page=article \&op=view\&path\%5B\%5D=124>. 
LOBATO, José Bento Monteiro. Cidades mortas. São Paulo: Globo Livros, 2007 [1919].

MACIEL, Laura Antunes. Cultura e tecnologia: a constituição do serviço telegráfico no Brasil. Revista Brasileira de História, São Paulo, v. 21, n. 41, p. 133.

MARINHO, Pedro Eduardo Mesquita de Monteiro. Ampliando o estado imperial: os engenheiros e a organização da cultura no Brasil oitocentista, 1874-1888. Tese (doutorado) - Universidade Federal Fluminense, Instituto de Ciências Humanas e Filosofia, Departamento de História, 2008.

. Engenharia imperial: o Instituto Politécnico Brasileiro - (1862-1880). Dissertação (mestrado em História) — PPGH da Universidade Federal Fluminense. Niterói: UFF, 2002 .

- Porta-vozes em uma era de incertezas: o Clube de Engenharia e a concepção de uma Inspetoria Geral das Estradas de Ferro. Revista Brasileira de História da Ciência, v. 3, p. 170-183, 2010.

MARQUESE, R. B. (2012) Capitalismo, escravidão e a economia cafeeira do Brasil no longo século XIX. Disponível em: <http://people.ufpr.br/-lgeraldo/textomarquese.pdf>. Acesso em: 14 abr. 2014.

MATTOS, Ilmar Rohloff de. O tempo saquarema: a formação do estado imperial. São Paulo: Hucitec, 2004.

MENDONÇA, Sonia Regina de Mendonça. A primeira política de valorização do café e sua vinculação com a economia agrícola do Estado do Rio de Janeiro. Dissertação (mestrado em História) — Universidade Federal Fluminense, Niterói, 1977.

. Ruralismo: agricultura, poder e Estado na Primeira República. vol. 1. Tese (doutorado em História). São Paulo: Universidade de São Paulo, 1990.

NABUCO, Joaquim. O abolicionismo. Petrópolis: Vozes, 1988 [1883]. p. 122.

OLIVEIRA, Geraldo de Beauclair Mendes de. A construção inacabada: a economia brasileira, 1822-1860. Rio de Janeiro: Vício de Leitura, 2001.

PAULA, Dilma Andrade de. Fim de linha. A extinção de ramais da Estrada de Ferro Leopoldina, 1955-1974. Tese (doutorado em História) — Universidade Federal Fluminense, 2000. RABELLO, Andrea Fernandes Considera Campagnac. Os caminhos de ferro da provincia do Rio de Janeiro. Ferrovias e café na 2a metade do século XIX. Dissertação (mestrado em História) - Instituto de Ciências Humanas e Filosofia, Universidade Federal Fluminense, Niterói, 1996.

SAES, Flavio A. Marques de. A grande empresa de serviços públicos na economia cafeeira, 1850-1930. São Paulo: Hucitec, 1986.

. As ferrovias de São Paulo, 1870-1940. São Paulo: Hucitec, 1981. 
SALLES, Ricardo. E o vale era escravo. Vassouras, século XIX. Senhores e escravos no coração do império. Rio de Janeiro: Civilização Brasileira, 2008.

SEGNINI, Liliana R. Petrilli. Ferrovias e ferroviários: uma contribuição para a análise do poder disciplinar na empresa. São Paulo: Autores Associados/Cortez, 1982.

SILVA, Antonio Morais. Diccionario da lingua portugueza. Rio de Janeiro: Editora Empreza Litteraria Fluminense de A. A. da Silva Lobo, 1889.

SILVA, Sérgio. Expansão cafeeira e origens da indústria no Brasil. 7. ed. São Paulo: Alfa Omega, 1986.

SUMMERHILL, William. Order Against Progress: Government, Foreign Investment, and Railroads in Brazil, 1854-1913. California: Stanford University Press, 2003.

TAUNAY, Affonso apud PESSAMILIO, Herci Maria Rebelo. A dinâmica social do café. In: PESSAMILIO, Herci Maria Rebelo et al. O café no Brasil. Ministério da Indústria e do Comércio. Instituto Brasileiro do Café. Rio de Janeiro: AGGS Indústrias Gráficas S/A, 1978. TELLES, Pedro Carlos da Silva. História da engenharia no Brasil — séculos XVI a XIX. v. 1, 2. ed. Rio de Janeiro: Clavero, 1994.

VARGAS, Milton (Org.). História da técnica e da tecnologia no Brasil. São Paulo: Unesp, 1994.

WIRTH, John. O fiel da balança: Minas Gerais na federação brasileira (1889-1937). Rio de Janeiro: Paz e Terra, 1982.

\section{Fontes}

REIS, Aarão Leal de Carvalho (Org.). Primeiro Congresso das Estradas de Ferro do Brasil. Archivos dos Trabalhos. Rio de Janeiro: Club de Engenharia, 1882.

REVISTA DO CLUBE DE ENGENHARIA. Rio de Janeiro: Imprensa a Vapor Lombaerts \& C./Tip. Leuzienger \& Filhos (Ano I, II, III, vol. I ao VIII — 1887-1889).

RIPB - REVISTA DO INSTITUTO POLITÉCNICO BRASILEIRO. Rio de Janeiro: Tip. Imperial Instituto Artístico/Tip. Leuzienger \& Filhos/Tip. Nacional (Tomos I ao XXXI - 1867-1906). 